\section{Nutritional gains of underprivileged children attending a day care center in S.Paulo City, Brazil: a nine month follow-up study}

\section{Recuperação nutricional de crianças empobrecidas matriculadas em creche na cidade de São Paulo, Brasil: um estudo de seguimento de nove meses}

\author{
Jose Augusto Taddei \\ Núcleo de Nutrição, Alimentação e Desenvolvimento Infantil \\ S. Paulo State Health Secretary and Emory University, International Health \\ Department \\ Correspondence: \\ R. Marselhesa, 630 \\ 04020-060 São Paulo, SP - Brasil \\ e-mail: taddei.dped@epm.br
}

\section{Michael J.Cannon}

\section{Lee Warner}

Emory University, Epidemiology Department and Centers for Disease Control and Prevention.

\section{Patricia Souza}

Silvya Vitalle

Domingos Palma

\section{Fernando Nóbrega}

Núcleo de Nutrição, Alimentação e Desenvolvimento Infantil, S. Paulo State Health Secretary

\section{Abstract}

The efficacy of a well-operated day care center in providing better nutrition to poor children in Brazil was assessed. We collected data for 9 months from 180 underfive children attending a day care center located in a slum. Every working day each child received at least $100 \%$ of the agegroup recommended dietary allowances plus iron fortified milk and, every six months, treatment for helminth infections. Statistical analyses were restricted to the 168 children (93\%) who had measurements from at least five months. As outcome variables, weight-for-height, height-for-age, and weight-for-age $\mathrm{Z}$ scores were dichotomized so that a $Z$ score $<-1$ indicated a child was at risk of malnutrition. We examined the proportion of children at nutritional risk in each month and used multivariate statistical techniques to adjust for confounding and to account for intra-subject correlation. The percentage of children at nutritional risk decreased over time, from $10.1 \%$ to $3.4 \%$ for weight for height, $29.8 \%$ to 15.2 $\%$ for weight for age, and from $50.0 \%$ to $44.8 \%$ for height for age. Most of the reduction took place between the third and fourth months of enrollment. The correlated data models for the three dichotomized outcomes showed a two to three-fold reduction in the occurrence of wasting and underweight. We concluded that attendance to well-operated daycare protects against nutritional risk, and approximately four months are required for a benefit to be seen.

Keywords: Nutritional status. Health services research. Child day care centers. Epidemiology. 
Avaliou-se a eficácia da freqüência a creche padrão em promover recuperação nutricional de crianças pertencentes a famílias de baixa renda. Foram coletados dados, por um período de nove meses, de 180 crianças que frequentavam uma creche localizada em uma favela. Em todos os dias úteis cada criança recebia no mínimo 100\% das recomendações dietéticas diárias, acrescidas de leite fortificado com ferro e, semestralmente, tratamento para parasitoses intestinais. As análises estatísticas se limitaram a 168 crianças (93\%) para as quais se dispunham de medidas de pelo menos cinco meses. Como variáveis resposta, os escores $\mathrm{Z}$ das relações peso para estatura, estatura para idade e peso para idade foram dicotomizados de forma que escore $\mathrm{Z}$ $<-1$ indicava risco nutricional. Foram estudadas as proporções de crianças em risco nutricional a cada mês e utilizadas técnicas estatística multivariadas para controlar eventuais fatores de confundimento e correlacão entre as medidas subsequentes da mesma criança.

O percentual de crianças em risco nutricional diminuiu no decorrer do acompanhamento, de $10.1 \%$ para $3.4 \%$ na relação peso estatura, de $29.8 \%$ para $15.2 \%$ na peso idade, e de $50.0 \%$ para $44.8 \%$ na estatura idade. A maior parte das reduções ocorreram entre os terceiro e quarto meses de frequência. Os modelos de dados correlacionados para as três variáveis resposta dicotomizadas evidenciaram reduções de duas a três vezes nos riscos nutricionais descritos pelos indicadores de peso-estatura (wasting) e peso-idade (underweight). Concluimos que a creche padrão diminui riscos nutricionais, sendo necessários aproximadamente quatro meses para que os benefícios sejam identificados.

Palavras-chave: Estado nutricional. Pesquisa em serviços de saúde. Creches. Epidemiologia.

\section{Introduction}

Over the last few decades the number of children in day care centers in urban industrialized societies has grown. This growth is due to the increase in the number of working mothers and to the increase in the number of single-parent families. In 1995 in the United States, $60 \%$ of the children under five years of age, approximately 13 million children, received non-parental care or attended an early education program $^{1}$.

Similar trends can be found in developing urban areas. For example, in the city of São Paulo, Brazil, the number of day care centers for low-income families has grown from 16 units in 1968 to 410 in 1984 and 692 in 1996. Approximately eighty thousand children from low-income families attended these institutions in $1996^{2}$.

The effects of day care on child growth and development appear to vary by income. In the U.S., day care center attendance increases the risk of infections and injuries, and may cause behavioral disorders due to lack of mother-child contact ${ }^{3-5}$. However, for disadvantaged children living in third world urban slums, whose homes and families put them at developmental risk, attendance to day care centers may improve health and nutrition by providing adequate food and a sanitary environment ${ }^{6,7}$.

Day care may also decrease inequality in developing societies. A recent World Bank assessment of poverty in Brazil has identified the increase in day care center availability for low-income families as the most promising social policy to reduce poverty $^{8}$. Day care centers can be placed in lowincome areas, targeting health and nutrition interventions towards the most impoverished children and, at the same time, allowing poor mothers to work.

Day care centers in developing countries need to be evaluated to determine their efficacy in promoting nutrition recovery for at-risk children. Although catch-up growth of undernourished children has been studied in hospital wards, nutrition rehabilita- 
tion centers and communities, little is known about catch-up growth in day care centers in developing countries ${ }^{9}$. In addition, most studies of nutrition recovery have relied only on the description of clinical cases, or have considered multiple measurements in the same subject without accounting for the correlation among them ${ }^{10}$, ${ }^{11}$. Using multivariate statistical methods that account for correlated multiple measurements, this study assesses the efficacy of a day care center in the city of São Paulo in improving the health of children at risk for malnutrition.

\section{Methods}

\section{Study Population and Procedures}

We collected data from children attending a day care center in a slum in the city of São Paulo, Brazil, from March 1996, to November 1996. A total of 180 children under five years of age attended the center during follow-up. All children were enrolled in the first or second month of follow-up. To be eligible for day care, children had to be upto-date with all required immunizations. Vaccines for tuberculosis, whooping cough, diphtheria, tetanus, measles and poliomyelitis are provided free by the Brazilian government. The children spent every working day from $8 \mathrm{AM}$ to $6 \mathrm{PM}$ at the day care center, where they participated in age-group appropriate learning activities. Every day they received five meals that provided at least $100 \%$ of age-group recommended dietary allowances ${ }^{12}$. Meals were planned by a nutritionist using computer software ${ }^{13}$. Food preparation and actual intake were supervised by the nutritionist, who made corrections when needed to guarantee food quality and adequate intake for each child. Since nearly every child has parasites due to poor sanitary conditions in their homes, in March and September each child received 40mg of albendazole to decrease intestinal infestation. To prevent iron deficiency anemia, every morning each child received a glass of milk fortified with $3.0 \mathrm{mg}$ of iron amino acid chelate ${ }^{14}$.

In order to monitor nutritional status, we used standardized procedures and instruments to obtain height and weight measurements for every child at the end of each month of enrollment. All measurements were taken by a nutritionist, (Souza ${ }^{15}$ ), assisted by the day care center nurse. Length was measured for children in the nursery classes (age $<18$ months), while height was measured for children in the pre-school groups (age 18 to 60 months). As we were interested in time trends, we restricted statistical analyses to the 168 children (93\%) who had measurements of height and weight from at least five months. Of these children, 143 (85\%) had nine consecutive months of follow-up. Overall, a total of 1,458 monthly observations were obtained. Timedependent covariates related to morbidity and day care attendance were recorded daily by each class instructor under the supervision of the nutritionist. Time-independent covariates were collected by a social worker upon enrollment in the day care center $^{15}$.

\section{Outcomes}

The outcomes of interest were three measurements of nutritional statusweight-for-height $\mathrm{Z}$ scores (WHZ), a measure of wasting or acute malnutrition; height-for-age Z scores (HAZ), a measure of stunting or chronic malnutrition; and weight-for-age Z scores (WAZ), a measurement of underweight. $Z$ scores for the three outcome variables were calculated using an Epi-Info routine which utilizes a NCHS/ WHO reference population ${ }^{16}$. We dichotomized the three outcome variables so that a Z score $<-1$ indicated a child was at risk of malnutrition, and a Z score $>=-1$ indicated no risk ${ }^{17}$.

\section{Exposure and Covariates}

Since we wanted to evaluate whether children experienced improvements in nutritional status over the course of the study, 
the exposure of interest was months spent in the day care center. In addition to recording day care center attendance, we collected data on covariates that might confound the observed relationship between exposure and outcomes. The following time-dependent covariates were measured for each month of observation: number of days each child was absent from the day care center (continuous variable); class of enrollment (nursery or pre-school); presence of diarrheal infection (yes or no); presence of skin infection (yes or no); and presence of respiratory infection (yes or no). We also measured eight time-independent dichotomous (yes/no) variables at baseline: birth weight less than $3000 \mathrm{~g}$; prior hospitalization of the child; whether the child resided in a home with running water; maternal education <= 4 years; whether the child had other siblings; whether the child was breastfed $<60$ days; age at enrollment $<18$ months; and whether the child had attended a day care center before the study began.

\section{Analysis}

To evaluate whether day care center attendance improved health over time, we examined the proportion of children at risk for nutritional in each month. We also used multivariate statistical techniques to adjust for confounding and to account for intrasubject correlation resulting from multiple observations per subject. We chose a marginal fixed effect model for correlated data that assumed an autoregressive correlation structure and robust variance estimator ${ }^{18}$. The model was fit using the generalized estimating equations (GEE) method with SAS's GENMOD procedure. Output from each model was in the form of eight prevalence odds ratios (POR), comparing the odds of being at nutritional risk in months two through nine with the odds in month one.

Using correlated data models for each of the three outcomes (i.e., WAZ, HAZ, and WHZ), we evaluated whether the 13 covariates were univariate confounders. We fit models containing only the exposure variable, and models containing the exposure and one covariate. For each of the 13 covariates, including the covariate singly gave prevalence odds ratios that differed by less than $10 \%$ from the POR's of the models with only the exposure variable. Therefore, we concluded that the covariates were not confounders in our data set. However, based on epidemiological and clinical knowledge, we included in our final models five covariates: class of enrollment (an indicator of age and type of care provided), prior day care attendance, and presence of diarrhea, skin, and respiratory infections.

\section{Results}

\section{Characteristics of the study population}

Many children enrolled in the study had characteristics associated with nutritional risk (Table 1). More than $40 \%$ weighed less than 3,000 grams at birth. Almost $70 \%$ had no running water at home. Two-thirds of mothers had received less than five years of schooling. Fewer than half the children were breastfed by their mothers for more than two months. Respiratory infections were common, with approximately half the children experiencing symptoms at least

Table 1. Characteristics of the 168 study participants at enrollment

\begin{tabular}{lcc}
\hline & Number & $\%$ \\
\hline Male & 106 & 63.1 \\
Prior hospitalization & 59 & 35.1 \\
Running water at home & 52 & 31.0 \\
Other siblings & 128 & 76.2 \\
Prior day care attendance & 98 & 58.3 \\
\hline & Mean & Standard \\
& & deviation \\
\hline Birthweight (grams) & 3100 & 698 \\
Maternal education (years) & 3.8 & 2.7 \\
Breastfed (days) & 88 & 69 \\
Age at enrollment (months) & 30 & 13 \\
\hline
\end{tabular}


once a month. Symptoms of diarrhea and skin infection were less frequent, each occurring in about $15 \%$ of children each month. The percentage of children with respiratory infections showed a slight increase over time ( $\mathrm{p}=0.01$ ), while slight decreases in diarrheal $(\mathrm{p}=0.01)$ and skin infections $(\mathrm{p}=0.08)$ were seen.

\section{Time trends in outcome variables}

At the beginning of the study, $10.1 \%$ of the children were at risk for wasting (WHZ $<-1), 29.8 \%$ were at risk for underweight (WAZ $<-1$ ), and $50.0 \%$ of the children were at risk for stunting $(\mathrm{HAZ}<-1)$. For all three measures of outcome, the percentage of children at nutritional risk decreased over time (Figure 1). During the course of the study, the percentage of children with WHZ $<-1$ decreased to $3.4 \%$ by month 9 . The percentage with $\mathrm{WAZ}<-1$ decreased to $15.2 \%$. Recovery from stunting risk occurred less frequently, with the number of children having $\mathrm{HAZ}<-1$ decreasing to $44.8 \%$. Most of the reduction in children at nutritional risk took place between the third and fourth months of enrollment. The decrease over time was statistically significant for WHZ $(\mathrm{p}<0.01)$ and WAZ $(\mathrm{p}<0.01)$, but not for HAZ $(\mathrm{p}=0.26)$.

\section{Modeling results}

Correlated data models were fit for each of the three dichotomized outcomes - WHZ (wasting), WAZ (underweight) and HAZ (stunting). The prevalence odds ratios (with 95\% confidence intervals) comparing months two through nine with month one are shown in Figure 2. The odds ratios for wasting (WHZ) for months 4 through 9 ranged from 0.45 to 0.28 and were highly significant, as the associated confidence intervals did not include the null value, $\mathrm{POR}=1$. These odds ratios represent a two to three-fold reduction in the occurrence of wasting in months 4 through 9 compared to month 1. Similarly, the odds ratios for underweight (WAZ) in months 4 through 9 ranged from 0.64 to 0.43 , representing an approximate two-fold reduction. This reduction was also significant, as evidenced by $95 \%$ confidence intervals which excluded the value one. The odds ratios for stunting for months 4 through 9 ranged from 0.78 to 0.92 , representing a small, but not statistically significant, protective effect.

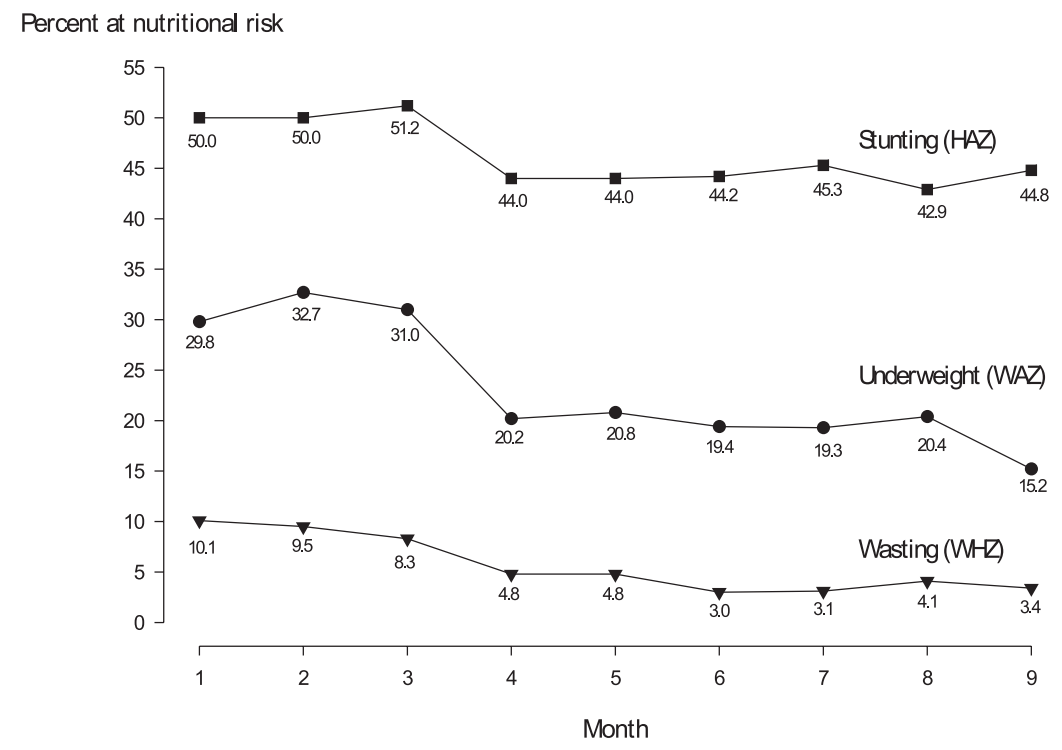

Figure 1. Percentage of children $(\mathrm{N}=168)$ at nutritional risk $(Z$ score $<-1)$ for each month of the study follow-up period. 

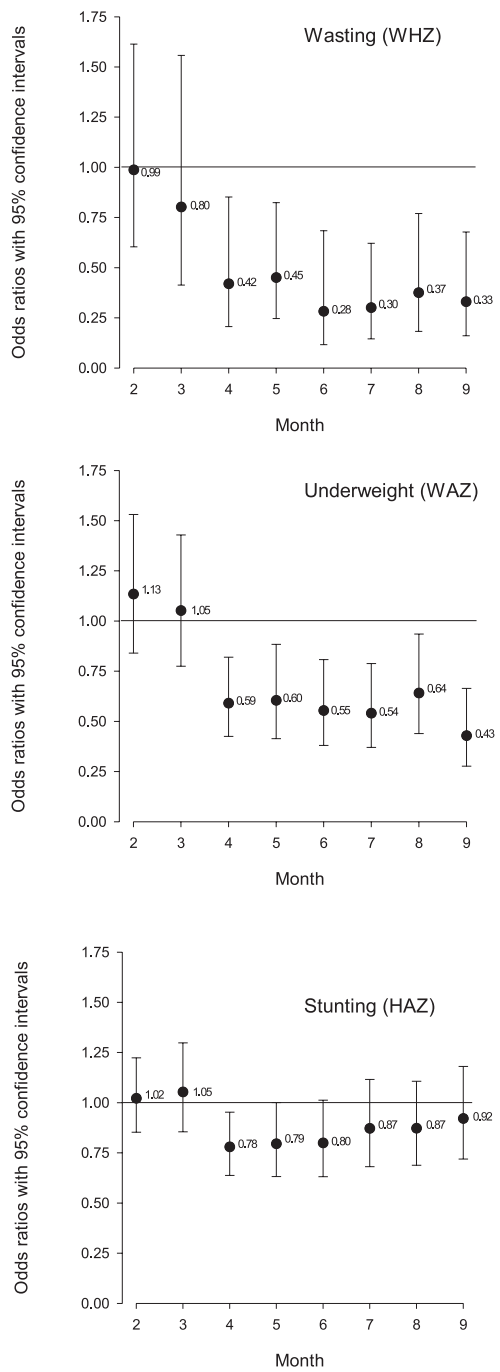

Figure 2. Prevalence odds ratios (PORs) showing the odds of being at nutritional risk for months 2 through 9 compared with the odds for month1. PORs are shown for wasting (WHZ $<-1)$, underweight (WAZ $<-1)$, and stunting ( $\mathrm{HAZ}<-1)$.

\section{Discussion}

Beginning in the fourth month of day care attendance, the percentage of children at risk for malnutrition was significantly reduced compared to baseline. Nutritional improvements were sustained over the remaining months of observation and were substantial for wasting (WHZ) and underweight (WAZ), but were modest for stunting (HAZ). This pattern of recovery from wasting and underweight is consistent with the pattern observed at nutritional rehabilitation centers, where the time for nutrition recovery in most reports has varied from three to four months ${ }^{19,20}$. The modest decreases in stunting were also consistent with current epidemiological and clinical knowledge. Even though stunting is the most common anthropometric deviation found among impoverished children, its correction depends upon longer periods of adequate care and, even under favorable conditions, may not be corrected completely ${ }^{21}$.

As we did not follow a non-day care control group, it is possible that the observed nutritional improvements were caused not by exposure to the day care center, but by other factors. The most important factor that might explain the improvements is the childhood aging process. Certain age groups can show improvements independent of interventions. Figure 3 shows this phenomenon using national survey data from São Paulo children who are similar to the children in our study, but most of whom were probably not enrolled in day care. A reduction in the percentage of children at nutritional risk occurred from age 1 to 2 for WHZ, WAZ, and HAZ. In most cases, after age 2 the percentage at risk increased, although for WHZ the percentage still decreased from age 2 to 3 .

There are a number of reasons why the normal aging process is unlikely to be the cause of the nutritional improvements we observed. First, in our models we controlled for enrollment class, an indirect measure of age. Second, by comparing the age distribution of our study children (Figure 4) with Figure 3, one can see that if the children had not been enrolled in day care, about as many would have experienced better outcomes as would have experienced worse ones. Third, most improvement in the models occurred between months 3 and 4, which is consistent with the time required for an intervention to cause nutrition recovery. Finally, our results did not change when we divided the children into those older and younger than 


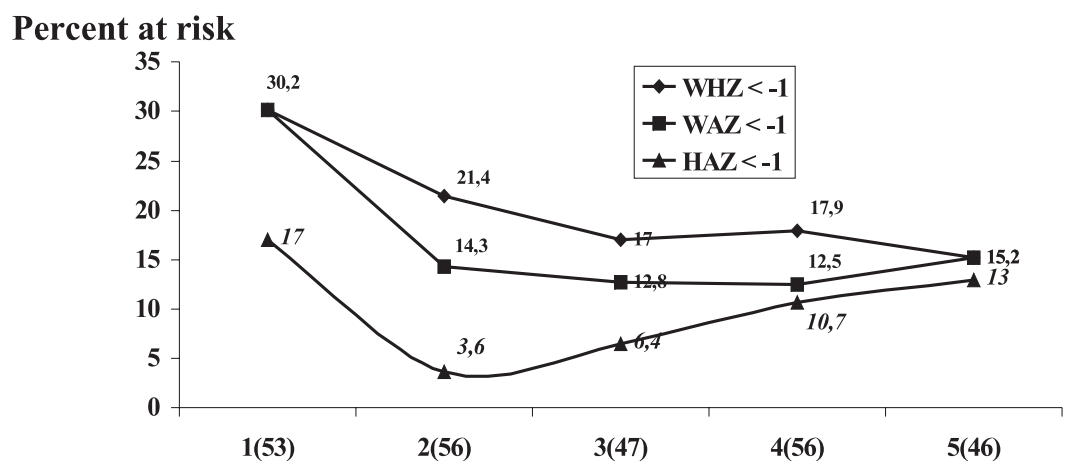

Age in years (children in each age group)

Figure 3. Percentage of children at nutritional risk ( $Z$ score $<-1)$ by age in years, taken from the national demographic and health survey, 1996 (Brazil, 1996). Consists of a sub-sample of 258 children from São Paulo state urban areas whose mothers had less than 5 years of formal education.

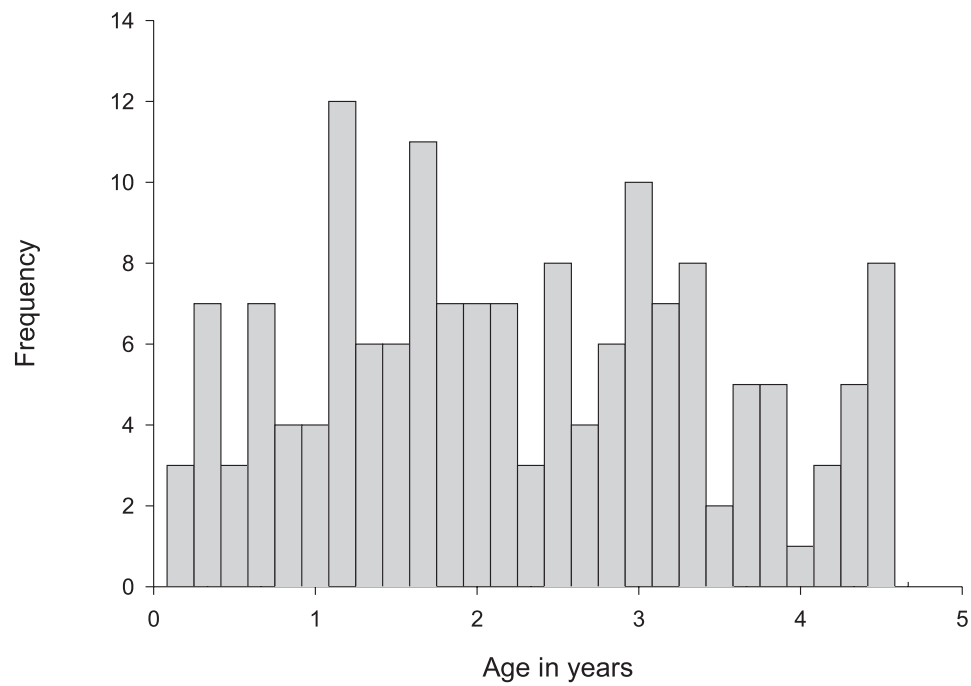

Figure 4. Age distribution of children enrolled in the study ( $N=168)$.

2, and refit the models for the two age groups. We found no statistically significant reduction in stunting for either age group, which was consistent with our original analysis. For underweight we still saw significant reductions in both age groups, and although there were not enough outcomes to fit wasting models for the younger group, we still saw significant reductions in the older group (data not shown).

Other factors which might explain the improvements we observed, include im- provements in health care, sanitary conditions at home, and family income. However, we closely observed the community during the study period and saw no widespread changes in these conditions. Seasonal variations could also potentially influence nutritional outcomes. In our study they were unlikely to have influenced nutritional improvement since seasons are not markedly different in São Paulo. Also, all the children lived in slums where the availability of goods and services does not change in dif- 
ferent seasons. Although the frequency of childhood infections varies in different seasons of the year, it is unlikely that a decrease in infections could explain the improvements we saw, since diarrhea and skin infections decreased only slightly, and respiratory infections increased. Even so, we controlled for infections in the analysis to ensure that they were not responsible for the nutritional changes observed.

The decrease in the proportion of children at nutritional risk $(Z<-1)$ is probably due to the joint effect of three day care-associated interventions: the provision of adequate diets, the iron fortification of milk, and the treatment of intestinal parasites. These interventions have been demonstrated to improve nutritional status in other studies ${ }^{22-25}$. Since all children received these three interventions, we were unable to determine which may have been the most important.

Recent studies have shown that the prevention of mild and moderate malnutrition has had more impact on child morbidity and mortality than the treatment of severe malnutrition ${ }^{26}$. While many children in our study were at risk for malnutrition $(\mathrm{Z}<-1)$, our sample did not show significant proportions of severe malnutrition $(Z<-2)$. Most of the children would be classified as normal or as having moderate or mild degrees of malnutrition. In an urban and partially developed city like São Paulo, few children have severe malnutrition ${ }^{27}$. Many who are severely malnourished do not survive to be enrolled in a day care center or are admitted to a hospital in order to recover. Thus, day care centers in low-income areas of cities like São Paulo may be important tools for reducing child morbidity and mortality because they prevent mild and moderate malnutrition rather than treating severe malnutrition ${ }^{28}$.

Well-operated day care centers in deprived urban populations are effective in promoting better nutrition in children. Because they also provide educational opportunities for underprivileged children while allowing poor mothers to work, the establishment of day care centers in developing urban areas is a promising social policy for decreasing poverty and improving health.

\section{References}

1. Hofferth SL. Child care in the United States today. Future Child 1996; 6(2):41-61.

2. Prefeitura do Município de São Paulo. Secretaria Municipal de Abastecimento. Programas de alimentação do Município. São Paulo; 1996.

3. Briss PA, Sacks JJ, Addiss DG, Kresnow M, O’Neil J. A nationwide study of the risk of injury associated with day care center attendance. Pediatrics 1994; 93: 364-7.

4. Caldwell, P. Child survival: physical vulnerability and resilience in adversity in the European past and the contemporary Third World. Soc Sci Med 1996; 43: 60919.

5. Webb RE, Foegere W, Papillon Y. An evaluation of the educational benefits of nutritional rehabilitation centres as measured by the nutritional status of siblings. Environ Child Health 1975; 2:7-10.
6. Hillis SD, Weigle K, Miranda CM, McCann M, Bender D, Stewart P. Supplementary feeding in Colombian child care centers and growth velocity. Pediatrics 1994; 96:1070-1.

7. Stephenson LS, Latham MC, Kurz KM, Kinoti SN, Brigham H. Treatment with a single dose of albendazole improves growth of Kenyan schoolchildren with hookworm, Trichuris trichiura, and Ascaris lumbricoides infections. Am J Trop Med Hyg 1989; 41:78-87.

8. The World Bank, Brazil. Poverty assessment. Brasília (DF); 1996.

9. Marcovitch H. Failure to thrive. BMJ 1994; 308: 35-8.

10. Mitchell WG, Ralph PL, Gorrel MA, Greenberg A. Failure to thrive: a study in a primary care setting: epidemiology and follow-up. Pediatrics 1980; 65: 971-7. 
11. WHO Working Group. Use and interpretation of anthropometric indicators of nutritional status. Bull World Health Organ 1986; 64:929-41.

12. American Dietetic Association (ADA). Position of the American Dietetic Association: nutrition standards for child care programs. J Am Diet Assoc 1994; 94: 363.

13. Anção NS, Cuppari L, Tudisco ES, Draibe S.A, Sigulem DM. Sistema de apoio à decisão em nutrição - versão 2.5 . [software] São Paulo: CIS/EPM/ UNIFESP; 1995.

14. Lost C, Name JJ, Jeppsen RB, Ashmead HD. Depleting hemoglobin in iron deficiency anemia in young children through liquid milk fortification with bioavailable iron amino acid chelate. J Am Coll Nutr 1998; 17:187-94.

15. Souza PC. Efeito da frequência a uma creche padrão na saúde e nutrição de 74 pré-escolares residentes em favelas [dissertação de mestrado]. São Paulo: UNIFESP;1997.

16. Dean AG, Dean JA, Coulombier D, Brendel KA, Smith DC, Burton AH et al. Epi Info, version 6: a word processing, database, and statistics program for epidemiology on microcomputers [computer program]. Atlanta, Georgia: Centers for Disease Control and Prevention; 1994.

17. WHO Expert Committee on Physical Status. The use and interpretation of anthropometry. Geneva; 1995. (WHO Technical Report Series, 854).

18. SAS Institute, Inc. SAS/STAT software: changes and enhancements through release 6.12. [computer program]. Cary, NC: SAS Institute; 1997.

19. Beghin ID. Nutritional rehabilitation centers in Latin America: a critical assessment. Am J Clin Nutr 1970; 23:1412-7.
20. Eisler M, Ravines LC, Ramirez JL. The Nutrition Rehabilitation Center. J Am Diet Assoc 1969; 55: 246-51.

21. Martorell R, Kettel Khan L, Schroeder DG. Reversibility of stunting: epidemiological findings in children from developing countries. Eur J Clin Nutr 1994; 48 suppl.1: S45-S57.

22. Hadju V, Stephenson LS, Abadi K, Mohammed HO, Bowman DD, Parker RS. Improvements in appetite and growth in helminth-infected schoolboys three and seven weeks after a single dose of pyrantel pamoate.

Parasitology 1996; 113:497-504.

23. Lawless JW, Latham MC, Stephenson LS, Kinoti SN, Pertet AM. Iron supplementation improves appetite and growth in anemic Kenyan primary school children. $J$ Nutr 1994; 124: 645-54.

24. Queiroz SS, Torres MAA. Anemia carencial ferropriva: aspectos fisiopatológicos e experiência com a utilização do leite fortificado com ferro. Pediatr Mod 1995; 32: 441-5.

25. Silva E.M.K. Avaliação do estado nutricional de crianças de creches públicas e crianças que receberam outros tipos de cuidados no município do Embú-SP, 1994/1995. [tese de doutorado]. São Paulo: UNIFESP;1996.

26. Schroeder DG, Brown KH. Nutritional status as a predictor of child survival: summarizing the association and quantifying its global impact. Bull World Health Organ 1994; 72: 569-79.

27. BEMFAM-Brasil. Pesquisa Nacional sobre Demografia e Saúde-1996. Rio de Janeiro; 1997.

28. Bengoa JM. Nutrition rehabilitation centers. J Trop Pediatr 1967; 12: 169-76. 